\title{
Chapter 15. Indic Transformation: The Sanskritization of Jawa and the Javanization of the Bharata
}

\section{S. Supomo}

This chapter gives an account of the earliest Indian contacts with Indonesia according to first millennium AD inscriptions from East Kalimantan and Java. It discusses the changes which occurred in social, religious and political organization, particularly in Java, as a result. The dissemination of literary into Indonesia is examined in detail and a comparison is made of the rather limited literary output of Śriwijaya (Sumatra) and the flowering of literature in Hindu-Buddhist Java. The Javanese not only adopted many literary works of Indian origin, but also transformed them in the process.

\section{Introduction}

Although contacts between the western mainland of Southeast Asia and India had existed since prehistoric times, it was only in the beginning of the Christian era that the Sanskrit civilization of India began to spread more rapidly across the Bay of Bengal into the western parts of the Austronesian world. The exact circumstances will probably remain unknown, but the following factors have been most often mentioned as the main causes of this new development.

The first was the expanding international trade which, from about 2000 years ago, greatly increased the number of traders and adventurers voyaging from India to Southeast Asia, and vice versa. Navigational skills were, after all, one of the characteristics that the Austronesians had possessed since prehistoric times. The existence of a Western Malayo-Polynesian language in Madagascar, which shows Sanskrit borrowings via Malay, is clear evidence that Austronesians had sailed as far as the east coast of Africa shortly after the introduction of Sanskrit words into Southeast Asia (Adelaar, this volume). Later evidence from Chinese accounts shows that the western Austronesians continued to supply transport facilities for merchants and cargoes from many parts of maritime Asia.

The second factor was the transformation of Buddhism into a world religion and the revival of the Hindu cult, especially the emergence of the bhakti movement (devotion to a personal God), which gave the impetus for Buddhist monks and Hindu Brahmans to travel to foreign countries to disseminate their faiths. It is now generally agreed that, while it may not be possible to disregard completely the possibility that the princes and warriors (kșatriya) and the traders (vaiśya) might have played a significant part in the process of the spread 
of the Indian influence, it was the brahmana (that is, the Hindu and Buddhist learned men) who were the main disseminators of the Sanskrit civilization in the region.

By the third century $\mathrm{AD}$, kingdoms organized according to the Indian conception of royalty had begun to appear in certain parts of Southeast Asia, first in the mainland and then slightly later in the Indonesian archipelago. The rulers of these kingdoms embraced the Indian religions, either Buddhism or Hinduism, and adopted Sanskrit as their official language, at least for ritual purposes. Sanskrit literature, especially the Mahābhārata and Rāmāyaṇa epics and the Pūranas, provided mythological resources.

\section{The Earliest Indic State: Kutai}

The oldest known inscriptions of the Indonesian archipelago are those on seven stone pillars, or yūpa ("sacrificial posts"), found in the area of Kutai, East Kalimantan, some twenty miles from the Makassar Straits. Written in the early Pallava script, these Sanskrit inscriptions were erected to commemorate sacrifices held by a King Mūlawarman, and are datable on palaeographical grounds to the second half of the fourth century AD (Vogel 1918; Chhabra 1965:50-52, 85-92; de Casparis 1975:14-18). They are only short inscriptions - in all no longer than 50 lines, the longest consisting of only three stanzas of four lines each - but they are the most important evidence that we have that testifies to the emergence of an Indianized state in the Indonesian archipelago prior to AD 400.

The inscriptions do not mention the name of this kingdom, but we have the names of three generations of rulers from one of them. They are Mūlawarman, the reigning king, who is styled the "lord of kings" (räjendra); his father Aśwawarman, entitled the "founder of the dynasty" (vanśa-kartr); and his grandfather Kundungga, the "lord of men" (narendra). It is generally agreed that Kundungga is not a Sanskrit name, and therefore he was most likely a native of the land. The fact that Kundungga's name is of native origin while both his son and grandson had Sanskrit names seems to indicate that it was not Kundungga, but his son Aśwawarman who was the first of his line to adopt the Hindu cult and was probably also the founder of the "new" kingdom based on the principles of the new faith. Accordingly, Aśwawarman was called the "founder of the dynasty" by later generations, and in the inscription he was appropriately likened to anśuman, "the sun", who was the mythical founder of the solar race of India (Chhabra 1965:51).

The inscriptions do not mention whether Aśwawarman embarked on a policy of expanding his influence to the surrounding areas, as was customary for the founder of a dynasty, but there is no doubt that his son launched such a policy. In one of the inscriptions Mūlawarman is said to have "conquered other kings in the battlefield, and made them tributaries, as did king Yudhișțira". This is no 
doubt a reference to the digvijaya episode in the Mahābhārata (Book 2), which describes the conquest of various countries in all directions by the Pāndawas, after which the rajaśuya sacrifice was performed and Yudhisțhira became the world ruler. And so, while his grandfather was only designated as a narendra ("lord of men") in the inscription, Mūlawarman was styled a rājendra ("lord of kings"), with all the neighbouring rulers paying tribute to him.

But who were these other kings who were conquered in the battlefield by Mūlawarman? Were they, like Mūlawarman himself, also rulers of Indic states, or were they chieftains of tribal communities in the surrounding areas? Obviously we are not in a position to give definite answers to such questions but, until new evidence is found which proves otherwise, it seems likely that they were the latter. Whereas in Kutai there are findings of various archaeological remains such as Hindu and Buddhist images, there has been no evidence, from inscriptions or from Chinese sources, which indicates that other kingdoms existed in the area. In the inscriptions those "other kings" are called pärthiva, and Kulke has suggested, on the basis of the etymology of this Sanskrit word, that they were landholders, comparable to the rakai of the Old Javanese inscriptions (Kulke 1990:6). We do not know what happened to this Kutai kingdom after the issuing of Mūlawarman's inscriptions, but it might have declined soon afterwards and those pārthiva might then have regained their former status as chiefs of independent tribal communities.

Some sort of a kingdom or a chiefdom did, however, apparently continue to exist in the region, as we find the name Tuñung Kute as one of the mandalikarạsțra ("ring-kingdoms") under the "protection" of Majapahit, which are enumerated in cantos 13 and 14 of the fourteenth-century Old Javanese poem Nāgarakṛtāgama (Pigeaud 1960-63. "Tuñjung Kute" occurs in stanza 14.1). There seems to be no doubt that this Tuñung Kute must have been the ancient name of present-day Kutai, because the name occurs in the list of the mandala located in the island of Tañjung-nagara, i.e. Kalimantan. (For a discussion on the concept of mandala in early Southeast Asia, see Wolters 1982:16ff.) It is even possible that Tuñjung Kute or one of its synonyms was the name of Mūlawarman's kingdom. If the name Kute (Kutai) is still used in present-day Indonesia, there seems to be no strong reason why the name that appears in this poem could not be that of the same kingdom that existed earlier. ${ }^{1}$ Many names of villages, districts, and kingdoms found in the inscriptions survive to the present, often with only slight modification.

\section{The Sanskritization of Jawa}

A similar case which shows the emergence of another Hinduized state in Indonesia is provided by the oldest dated inscription from Central Java, found in Canggal, a village in the region of Kedu (Sarkar 1971-72:I, 15-24). This Sanskrit inscription tells us about the foundation of a lingga, the phallic symbol of God Śiva, by a 
King Sañjaya in AD 732. It also mentions his father, named Sanna or Sannāha, who had "in the fullness of time, gone to enjoy happiness in the heaven which is the accumulated results (of his meritorious deeds)". ${ }^{2}$ Since Sannāha, despite its spelling, is not a Sanskrit word, it seems reasonable to suppose that it was a Sanskritized Javanese name. We have a similar case in the name of Sañjaya's successor. His Javanese name, as it appears in the Old Javanese Mantyasih I inscription of AD 907, was Panangkaran, but in the Sanskrit Kalasan inscription dated 778 his name appears in its Sanskritized form as Pạ̣aṃkarana (Sarkar 1971-72:II, 64-81; I, 34-40).

Some geographical names may also appear in Sanskrit forms. Thus the name Tārumā, mentioned in the fifth century inscriptions found in western Java, may have been a Sanskritized form of an indigenous name related to tarum, "indigo" (Gonda 1973:77). Another example is Yava which according to Gonda "forms a vexed question". The name Yavadvipa, "Island of Barley", for Java and Sumatra, probably even for Kalimantan, was already known in early Sanskrit literary works (Wheatley 1961:177-179). But since barley is grown in neither island, Gonda (1973:348-350) argues that the original name was Jawa, which was a word for "Indonesian, indigenous" and could have applied to both Java and Sumatra, to their inhabitants, products, languages, etc. Indian navigators and colonizers interpreted the word, by way of popular etymology, as yava-, "abundance of barley" and named the island accordingly. Then, under the Sanskritizing tradition, the new name "Yava" returned to Java as we find it in the Canggal inscription. ${ }^{3}$

Since Sannāha apparently did not have a Sanskrit name it seems very likely that Sañjaya, like Aśwawarman of the Kutai inscription, was the first of his line to adopt the śivaite cult, establish a "new" kingdom, and assume a Sanskrit name. Like Aśwawarman he was regarded as the founder of the dynasty by later generations, as is evident from the Mantyasih I charter. This is an Old Javanese inscription issued by King Balitung in AD 907, in which Sañjaya's name appears at the head of a list of eight successive rulers of Mataram. Significantly, in this charter he is simply entitled rakai Mataram sang ratu Sañjaya, while all the other rulers are recorded with a more exalted title, Śrimmahārāja, e.g. Śrimmahārāja Panangkaran, Śrīmahārāja Panggumulan, etc.

However, Sanna himself was also a ruler. This is clear from the Canggal inscription which tells us that he, "by means of conciliation and gift, ruled the subjects in a proper way, out of attachment, just like a father (taking care of) the child from his very birth" (verse 8c). In the context of the organization of communities in ancient Java, the choice of the simile "like a father (taking care of) the child" to describe the relationship between the ruler and the subjects seems to be very apt. As is known from the Old Javanese inscriptions, the smallest indigenous community in ancient Java was the wanua ("village, settlement"). 
Its inhabitants, especially those born there, were called anak wanua or, from the end of the tenth century, anak thāni ("children of the village"). They were probably the descendants of the original founders of the village concerned. The wanua was governed by a board of elders presided over by the first among equals, the rāma, the primary meaning of which was "father" (van Naerssen 1977:37; de Casparis 1990:62, note 6). By using such a simile, the author of the inscription might have intended to indicate that Sanna was a rāma, or, if he were not one, that he governed his subjects in the manner proper to a rāma.

The latter seems to have been more likely. We know from the inscription Mantyasih I that his son Sañjaya was a rakai, one level higher than a rāma in the social hierarchy of ancient Java. A rakai was the head of a territorial unit called watak or watěk ("group"), which consisted of several wanua. The rakaiship must have had its origin in prehistoric times. As van Naerssen has argued, with the introduction of wet-rice cultivation a more complicated system of irrigation was required and co-operation by the several wanua which depended on water of the same river or its tributaries therefore became necessary. Such an irrigation system needed a head whose authority reached beyond that of a single wanua, and so a leader, rakai, was elected from among the rāma (van Naerssen 1977:37). It appears from the inscriptions, however, that in most cases the villages belonging to the same watěk had become so dispersed that they no longer formed a contiguous territorial unit. By the tenth century a watěk might have comprised villages that were located in different parts of central and/or eastern Java, and the names of the well-known watěk such as Hino, Halu and Sirikan gradually lost their original territorial connotation. ${ }^{4}$

It has been suggested that the word rakai or rake was derived from raka, meaning "older brother" (Stutterheim 1933:165; van Naerssen 1977:37). Such an explanation, however, is now no longer acceptable. It has been pointed out that the word raka "never occurs in the inscriptions with the meaning of 'older brother', nor with any other meaning" (Barret Jones 1984:93), and the form raka $i$ is not in fact found in any original inscriptions (de Casparis 1990:56). Moreover, considering that ranking based on age is a very important principle among Austronesian peoples, one would expect that a kinship term indicating an older age group than "father" would be used to denote a position higher than rāma. It seems more likely, therefore, that the word rakai and variants such as rake, reke and raki, is related to ra-(ka)ki or ra-kya, the primary meaning of which is "elder, grandfather". 5

The highest authority in the autochthonous hierarchical system of ancient Java was the ratu. As far as we can see from the inscriptions, while rakai apparently no longer had direct relationships with the wanua from which they or their ancestors came, a ratu still maintained close ties with his own watěk, as is evident from the use of hi rakai title beside his ratu title. Thus, as we have 
seen, Sañjaya is recorded as rakai Mataram sang ratu Sañjaya in the Mantyasih I charter. Since Sannāha, as we shall see below, was also a ratu, it seems reasonable to suppose that he himself was also a rakai like his son.

The word ratu, or its cognates, is found in many languages which belong to the Austronesian language family with a variety of meanings, such as Tagalog dàto ("high priest"), 'Toba Batak datu ("sorcerer"), Malay datok ("head of a kin group"), and Fijian ratu ("title of rank before names of males who are chiefs"). Based on these various meanings, Blust (1980:216-217) suggests that the ProtoAustronesian * datu had at least four components of meaning, namely: (1) political leader, chief; (2) priest, custodian and administrator of customary law, medical practitioner; (3) aristocrat, noble; and (4) ancestor, grandfather, elder.

Thus the Old Javanese ratu, like rāma and rake (or rakai), may have developed from a kinship term meaning "ancestor, grandfather" to mean "political leader, chief". In terms of ranking rāma ("father") was head of the smallest unit, the wanua; rake ("elder, grandfather") was head of the watěk; and ratu ("grandfather, ancestor") was the highest in the hierarchal system.

Since Sañjaya was given Sanskrit titles meaning "king", i.e narapati and rāja, in the Canggal inscription (in verses 1 and 11 respectively), it is obvious that the author of the inscription, and most likely local Sanskrit scholars in general, considered ratu as the equivalent of Sanskrit rāja, "king". In this meaning (sang) ratu also occurs frequently in the Old Balinese inscriptions, especially during the reign of Ugrasena (915-39) (Damais 1949:29; Goris 1954:II, 296). $D \bar{a} t u$ also occurs in the Old Malay inscriptions of Śriwijaya, probably with the meaning of "governor of provinces", but kadātuan, significantly, was used for "royal residence" (de Casparis 1956:38, 345), resembling Old Javanese kadatwan ("royal residence, kingdom") and Modern Javanese kraton.

Like Sañjaya, Sannāha was also entitled rāja in the Canggal inscription (verse 8). So, he too must have been a ratu during his lifetime. In fact, he may have been the descendant of a long line of ratu, as the inscription specifically says that he was rājogrodagrajanmā, that is "a king of a very noble lineage". Likewise, Kundungga of the Kutai inscription must also have been a ratu, or whatever word was used in Kutai at that time to denote "political leader, chief", for in the inscription he was called a narendra, which is synonymous with Sañjaya's designation as narapati ("lord of men").

We may thus conclude that both Aśwawarman in Kutai and Sañjaya in Mataram did not actually found new kingdoms or principalities, but merely transformed the old established kadatwan into new räjya. It is moreover evident from the great number of official titles occurring in the Old Javanese inscriptions, 
the overwhelming majority of which are non-Indian and non-Sanskritic (Sarkar 1971-72:I, xix), that the new kingdom was largely a continuation of an older one.

The establishment of these new kingdoms obviously took place only after their rulers had decided to adopt Hinduism. Although it is often said that one is Hindu only by birth, the process of "Hinduization", which is sometimes given the more general term "Indianization" or "Sanskritization" (Hall 1981:12; Coedès, 1968:15-16; Mabbett 1977) seems to have occurred throughout the long history of India and still continues to occur (Srinivas 1966:1; Coedès 1968:25). It has been pointed out by Srinivas (1989:63) in this context that it was the second varna, the kșatriya, that "seems to have been the one most open, accommodating all kinds of groups, indigenous as well as alien, the only necessary qualification being the effective possession of political power". For the elevation of a native chief to the level of kșatriya the Brahmanic rite of vrātyastoma must have been performed by Brahmans. Accordingly, in areas where there was no established Brahman the chief either had to import some from outside - offering them gifts of land and other inducements - or even create them himself from amongst ambitious local groups (Coedès 1968:24; Srinivas 1989:63).

Perhaps in order to show that one had the necessary qualifications - the effective possession of political power - it seems to have been mandatory to announce one's conquest of surrounding areas in inscriptions. Thus we read, for instance, that Mūlawarman had "conquered other kings in the battlefield, [and] made them his tributaries" (Kutai inscription), and that Sañjaya had overthrown many "circles of feudal lords" (Canggal inscription).

As far as the need for the Brahmans to perform the necessary rites is concerned, the Kutai inscriptions explicitly tell us that the sacrifices held by Mūlawarman were performed by Brahmans who "had come there". At this early stage of the Sanskritization of the Indonesian archipelago they were likely to have been Indian Brahmans, but it is also possible that they were Austronesians who had acquired a priestly education in India and who came from other parts of the country for special occasions. Whatever the case, they must have come there on the invitation of the king, who then rewarded them with religious gifts, land and great wealth (up to twenty thousand and probably forty thousand cows are mentioned in the inscriptions - though the numbers were most likely exaggerated). Some may have left soon after the events, but a number of them must have decided to stay, forming the nucleus of a growing number of indigenous learned men. A Chinese record tells us that in the kingdom of $\mathrm{P}^{\prime}$ anp'an (fifth century AD) "are numerous brahmans come from India in search of wealth. They are in high favour with the King" (Wheatley 1961:49). 
It is clear from the above examples of the Hinduization of Kutai and Mataram that Hinduism - or Buddhism in cases where the rulers, for one reason or another, preferred the Buddhist monks - was disseminated by Brahmans invited there by the local rulers, and that these religions spread principally among the limited circles of members of the royal courts. It was, as Coedès (1968:33) puts it, "essentially an aristocratic religion which was not designed for the masses". And, like the "new" kingdom which still retained many of the essential parts of the old system, the new cult also contained many autochthonous religious beliefs. Thus one could point out, for instance, that behind the new Indian deva there was the ancient Javanese hyang, Old Javanese for "deity" (indeed the new deities were given the honorific hyang, e.g. hyang Śiwa, hyang Wișśnu); that śiwa was easily accepted as the highest God because, as the son-in-law of Mount Himalaya, he could be related to ancient worship of the Great Mountain; that the Javanese candi ("temples") can be identified as successors of the terraced religious sites of prehistoric times; or that the best known Javanese Buddhist monument, Borobudur, can only be understood properly in the light of ancestor worship (de Casparis 1950:188; Holt 1967:35-38).

It is clear, then, that the adoption of the Indian concept of kingship and various forms of Sanskritic culture and Indian religions did not lead to fundamental changes throughout the Indonesian political and social order. ${ }^{6}$ The sheen of these imported religions and cultural forms, to borrow a much quoted metaphor, "is a thin and flaking glaze", under which the whole of the old indigenous forms has continued to exist (van Leur 1967:95).

Nevertheless, significant changes did occur as the result of the penetration of the Sanskritic culture into the western parts of the Austronesian world. There seems to be little doubt that Sanskritization provided the necessary ingredients to enable the local cultures, especially those that had had more intensive contacts for a lengthy period of time, to produce cultural manifestations distinctly different from those of other Austronesian people who had no direct contacts with Sanskritic culture. Without the infusion of the Indian conception of royalty, it is extremely doubtful whether local polities with the relatively small-scale systems of political integration and ranking which were the common features of prehistoric Austronesian societies, could have developed into "true states with specialised bureaucracies and the powers to maintain allegiance by force" (Bellwood 1985:146-148). And without the foundation of such states it is very unlikely that religious monuments on the scale of the universally acclaimed temples of Borobudur and Prambanan - or even the smaller ones, the remains of which are scattered all over central and eastern Java as well as in many other places outside Java — could ever have been built. 


\section{The Spread of Literacy}

Another heritage which the Indonesians would never have had without Sanskritization is of course the Indian-based writing system and written literature derived from, or inspired by, Sanskrit literary works. This script and the literature are without doubt the most enduring elements of the adopted Indian culture.

Written literature, like Buddhism and Hinduism, entered the MalayoIndonesian archipelago through the main gates of the kraton (palaces). Merchants may have introduced Indian script for the first time, perhaps inadvertently, when they brought merchandise such as seals, rings and other precious objects, engraved with Sanskrit names, into a trading port. Thus, for instance, different types of Brahmi script (datable from the second to the fifth century AD) engraved on such precious objects have been discovered at Oc Eo, the site of an ancient trading port in southern Vietnam (Coedès 1968:7; de Casparis 1975:12), while a type of Brahmi or Kharoshthi script datable from the third century BC to the fourth century $\mathrm{AD}$ inscribed on the body sherd of an open dish-like vessel was recently found at Sembiran on the northern coast of Bali (Ardika and Bellwood 1991:225-226). More systematic dissemination of literacy, however, must have been carried out by the Hindu Brahmans and the Buddhist monks, for whom the study of books was always a significant part of daily activities. We read in a Chinese record, for instance, that in the third century kingdom of Tun-sun (in the Malay peninsula) there were more than a thousand Brahmans. The record tells us that they did "nothing but study the sacred canon, bathe themselves with scents and flowers, and practise piety ceaselessly by day and night" (Wheatley 1961:17). Those Brahmans came to certain kingdoms by invitation of the kings, then for one reason or another decided to stay and become guru. People would have gathered to hear their teachings and to study under their personal guidance.

In the beginning, disciples must have been limited to a small number of people, drawn mainly from what Srinivas (1989:63) calls "some ambitious local group" who aspired to become Brahmans, and probably also from other members of the royal courts. This constituted the nucleus of the local learned men. Proficiency in the Sanskrit language and literature must have been one of the primary requirements for those aspiring to be allowed into those elite groups. This is evident from the earliest inscriptions found in the archipelago from Kutai (around AD 400), western Java (fifth century) and central and eastern Java (seventh and eighth centuries) — all of which are written in Sanskrit, using Sanskrit metres, and are either religious or eulogistic in nature. Comparing the Kutai inscriptions with those found in India, Vogel (1918:216-218) says that the former indicate "a very fair knowledge of Sanskrit", and that as far as metrical exigencies are concerned they are "irreproachable". 
It was among such small groups of learned men that literacy evolved, slowly at first, but gradually gaining momentum and spreading to the wider circles of society. The importance of writing as a medium of communication must have soon been recognized by the rulers. Using writing, a king would be able to put his orders in a concrete, visible form, transportable to a distance, so that he would always be symbolically present among his subjects. As a Javanese author of an inscription dated 1296 expresses it, "They [the receiver of the 'supreme favour of His Majesty the King' and his descendants] will keep the Sacred Royal Order as physical protection: this charter sealed with the emblem of Krtarājasa Jayawardhana, to be written down on one of the three kinds of material, bronze, ripta (palm-leaves?), or stone; [is] to be worshipped once a year, placed under a yellow parasol, to the accompaniment of music, as though it were the king himself" (de Casparis 1975:7).

While literacy by itself would not necessarily result in the increased political power of the king and the expansion of the state, it would no doubt facilitate effective control of the whole realm. A local power, or even a regional kingdom, may be able to do without it, but for an imperial kingdom, literacy must be a crucial factor in maintaining its territorial integrity. ${ }^{7}$ As Gough (1968:71) argues, "It does seem improbable, that centralized states containing more than about a million people can exist, or can hold together easily, without some use of writing for political administration". While the number of one million may be somewhat arbitrary, there seems to be little doubt that writing "provides a reliable method for transmitting information between the centre and the periphery, and hence mitigates the fissive tendencies of large empires" (Goody 1968:1-2).

Thus by the seventh century literacy appears to have spread to wider circles of the population. A Chinese record says that in the kingdom of $\mathrm{P}^{\prime}$ an-p' an (located in the Malay peninsula): "The people all learn the brahmanical writings and greatly reverence the law of Buddha" (Wheatley 1961:48). Although it seems very unlikely that the whole population of $\mathrm{P}^{\prime} \mathrm{an}-\mathrm{p}^{\prime}$ an was really literate, the accounts indicate a certain degree of widespread literacy in that kingdom and probably in some other parts of the Malayo-Indonesian archipelago as well. We know from other Chinese accounts that in the seventh century, Holing (Walaing in central Java) and Fo-shih (Śrīwijaya in southern Sumatra) were famous centres of Buddhist learning. Chinese travelling to, or returning from, a pilgrimage to India often stopped there, and sometimes stayed for a considerable length of time, during which they may have studied Sanskrit grammar and copied or translated religious texts, sometimes under the guidance of local scholars (Coedès 1968:79-82). 


\section{Śrīwijaya: A Centre of Learning?}

For a communication to be effective, the language of the message sent by a speaker obviously has to be properly understood by those for whom the message is intended. Writing as an instrument of communication would be of no use if the language represented by these signs were incomprehensible to readers. Hence the spread of literacy would inevitably bring the vernacular languages of the texts into prominence.

It was not a coincidence, therefore, that some of the oldest inscriptions written in any vernacular of the Austronesian language family were issued by the rulers of Śrīwijaya, the first known imperial kingdom of the region, whose suzerainty at the peak of its power was widely acknowledged in the western parts of the Malayo-Indonesian archipelago, so much so that one of its rulers, writing to the Sung emperor in 1017, proudly referred to himself as "the king of the ocean lands" (Wolters 1970:1).

Six inscriptions from early Śrīwijaya (dated between AD 682 and 686) have so far been found in areas of southern Sumatra - three in Palembang, one in upper Jambi, one on the island of Bangka and another in Lampung - and these probably indicate the extent of the area under its effective control at this early stage of its long history (Coedès 1968:82-85; van Naerssen 1977:31-36). All these inscriptions are written in Old Malay, using a later type of Pallava script which is related to the script used in the Kutai inscriptions. Some adaptations were of course required. For instance, although the alphabet used for Sanskrit possessed many more signs than required for representing Old Malay and other Austronesian languages, it does not have a symbol for the phoneme $\breve{e}$. To overcome this problem, the Śriwijayan scholars simply used the "zero mark", using the two consonants between which the $\breve{e}$ was pronounced as a ligature, e.g. writing tmu for tĕmu ("to meet"). Whoever worked out these adaptations must have been scholar(s) of some influence, for most of the principles used in the writing of the early Śriwwijaya inscriptions continued to be used by later generations of scribes of Old Javanese and Old Balinese inscriptions and manuscripts. ${ }^{8}$

At about the same time as the inscriptions were issued, a well-known Chinese pilgrim, I-tsing, stopped in Śrīwijaya for six months in 671 to study Sanskrit grammar while on his way to India, and for another four years between 685 and 689, during which time he copied and translated Buddhist texts into Chinese. In his memoirs I-tsing tells us that: "In the fortified city of Fo-shih, there are more than a thousand Buddhist priests whose minds are bent on study and good works. They examine and study all possible subjects exactly as in Madhyadeśa [India]" (Coedès 1968:81; Takakusu 1966:xxxiv). I-tsing even tells us that while he was in Śrīwijaya, śākyakīrti, one of the four most distinguished Buddhist 
scholars at that time, was residing there (Takakusu 1966:184). It is clear from Itsing's accounts, and confirmed by the inscriptions, that by then Śriwwijaya was not only an established kingdom with considerable power over both sides of the Straits of Malacca, but was also a famous centre of learning.

In such an environment it is reasonable to expect that some sort of Old Malay literature must have developed in the kadatuan of Śrīwijaya. If I-tsing was able to complete "a new translation of suutras and sāastras" into Chinese during his stay in Śriwwijaya, one would expect that the Malay scholars would have done the same into Malay, or even produced original literary works. No such works, however, have come down to us. This is perhaps not surprising, considering that Śrīwijaya did not have its "Bali", the small, insulated island to which old Javanese literature owes its survival to the present day. But even in later Malay literature - the product of the Malay courts of Malacca and its successors, which claimed to be the heir to the Śriwijayan cultural tradition (Wolters 1970, 1982:22-24) — we cannot find any traces of written Old Malay literature. On the contrary, it is evidence of the influence of the Old Javanese cultural tradition that we find in later Malay literature. Of the half a dozen or so works listed in Chapter III (The Hindu Period) of Winstedt's A History of Classical Malay Literature, most are derived from Javanese sources such as the twelfth century Old Javanese poems Bhāratayuddha and Bhomakawya (Bhomāntaka), and others from the oral tradition, e.g. the Hikayat Seri Rama (Winstedt 1977:24-27). ${ }^{9}$

Now, apart from the absence of any trace of Old Malay literary works, we also find hardly any architectural remains from the Śrīwijaya period. One explanation usually offered for this is that, despite its fabulous wealth, as a maritime power Śrīwijaya did not possess the necessary manpower to build great edifices comparable to, say, the Borobudur; whereas the agricultural states of Java, with their "administrative machinery expanding in patrimonial, bureaucratic forms", were able to mobilize the needed manpower from the docile peasantry (see e.g. van Leur 1967:96-97).

It seems more likely, however, that lack of manpower was not the main reason for this apparent absence of building activities in Śriwwijaya throughout its long history. Had the rulers of Śriwwijaya had the inclination to build large religious monuments there seems little doubt that they would have been able to obtain the necessary manpower to build them. We know from the Kedukan Bukit inscription of AD 683, for instance, that the king had an army of more than twenty thousand soldiers at his disposal to accompany him on his siddhayātrā (a journey to obtain supernatural prowess). As Hall has pointed out, an emphasis on the maritime aspect of Śriwijaya, while in the main correct, tends to neglect the important relationship between the Śriwijaya ports and their hinterland, from which this large force of twenty thousand soldiers could have been recruited (Hall 1985:79-80). We also know from the writing of the 
Arab geographer Mas'ūdi (dated AD 995) that the kingdom of the islands of Zābag (among which were "Kalah and Sribuza and other islands in the China Sea") had "an enormous population and innumerable armies". "Even with the fastest vessel", Mas'ūdi says, "no one can tour these islands, all of which are inhabited, in two years" (Coedès 1968:131).

Lack of manpower, therefore, can not be used to explain why there are hardly any architectural remains from the whole Śrīwijaya period, spanning at least four centuries (from the seventh to the eleventh century), or even seven centuries (to the fourteenth century). Considering the fact that there are also no traces of literary works from this great empire, the conclusion seems to be that either the greatness of Śrīwijaya is merely another myth, comparable to that of Prapañca's Majapahit (Supomo 1979), or that the rulers of Śriwwijaya had entirely different priorities from those of their Javanese counterparts. That is, to quote Coedès:

After having become a great economic power, śrīvijaya seems to have neglected the spiritual values that attracted the Chinese pilgrim I-ching there in the seventh century. In fact, while the Javanese kings were covering their island with religious buildings, the śrivijayan sovereigns were preoccupied with superintending the traffic straits rather than building lasting monuments, and they have left us only insignificant brick towers and a very small number of inscriptions (1968:131; cf. van Leur 1967:106-107).

\section{"Temples of Language" in Ancient Java}

The Javanese rulers, however, did not only cover their island with candi silā, "temples of stone", but they also commissioned scores of poets and other literati to create what they called caṇ̂i bhạșa, "temples of language" ${ }^{\prime 1}{ }^{10}$ Building "language temples" turned out to be a wiser decision than covering the whole of Yawabhūmi with "stone temples", and even more so than hoarding fabulous wealth as the rulers of Śriwwijaya did in Suwarnabhūmi ("Land of Gold", i.e. Sumatra).

The oldest known dated Old Javanese inscription is from AD 804, that is almost one and a half centuries after the Old Malay inscriptions of Śrīwijaya. But, unlike Śrīwijaya where no more Old Malay inscriptions were apparently issued, hundreds of Old Javanese inscriptions have been found in Java, covering a period of more than six centuries. Since there must have been some connection between the level of literacy and the issuing of charters in the vernacular language, the abundance of the Old Javanese inscriptions must be an indication of the extent of literacy in ninth-century Java. This is perhaps only to be expected. During the seventh century, Walaing (Chinese: Holing) was apparently already such a famous centre of learning that a Chinese scholar went 
there to translate Buddhist texts into Chinese under the guidance of a Javanese guru. The erection of the Buddhist Borobudur and the śivaite Prambanan temple complexes, probably during the first half of the ninth century (Soekmono 1979:457-472; de Casparis 1956:309-311), shows that the dynastic changes that occurred in central Java after Sañjaya's accession to the throne did not diminish the importance of the region as a centre of learning. The thousands of bas-relief sculptures of Borobudur, which are based on various Buddhist texts (Krom 1927; Bernet Kempers 1980), and those of Prambanan based on a version of the Rāma saga (Stutterheim 1989), are clear testimony of continued vigorous study of literary texts.

It is not surprising, therefore, that the oldest "temple of language" that has come down to us, the Rāmāyana kakawin, was also the product of the central Javanese period. Surprisingly, this poem is based neither on the best-known version of the Rāma sagas, namely Valmiki's epic, nor on the version depicted in the bas-reliefs of Prambanan temple, but on the Rāvanavadha, "The slaying of Rāvaṇa", a sixth or seventh century poem by an Indian poet named Bhați. The choice of Bhați's poem, rather than Valmiki's epic, to serve as the poet's model in writing his poem, is remarkable. For the latter is not only the best-known version of all the Rāma sagas, but its language is also much easier than that of the former. Bhați himself says of his work that this poem "can be understood only by a commentary; it suffices that it is a feast for the clever and that the stupid come to grief in it as a result of my love for learning" (Keith 1956:116). Whatever reasons prompted the choice, however, the completed result was without doubt a masterpiece, the gem of all that has been produced by the Old Javanese kawi, "poets". To later generations it became the adikakawin, that is the first and foremost among the Old Javanese poems (Hooykaas 1958). It is also testimony of the high level of scholarship that must have existed in central Java at that time. The poet's ability to grapple with a text which posed so many problems clearly shows that his knowledge of Sanskrit must have been considerable and that he must have had complete mastery of his own language to have been able to render this difficult Sanskrit prototype satisfactorily. With the creation of both temples of stone and of language of the magnitude of the Borobudur and the Old Javanese Rāmāyaṇa, it is no wonder that Java of the ninth century continued to attract people from other countries. An inscription from Champa, for instance, tells us that a high official from what is today the central coast of Vietnam went on a pilgrimage to Java "to acquire the magical science". "The pilgrim's quest", comments Wolters (1982:27), "may epitomise Java's reputation for possessing esoteric knowledge".

The obvious advantage of the "temple of language" over "temple of stone" is of course its transportability. Once completed, a book, or more likely its copies, could be transported to the remotest part of the country. Even in those 
days it was apparently not uncommon to purchase books and build up some kind of a library in one's residence in the countryside. Prapañca tells us in the Nāgarakṛtāgama 29.2 that his friend, Kṛtayara, who lived in a village some distance from the capital, used to occupy himself "with the appraisal of kirti (valuable) books. Having been bought they were well taken care of, put into safe keeping" (Pigeaud 1960-63). In fact, one does not have to transport literature in its physical form to convey its message. Once its contents have been mastered, one can leave the book aside and relay its message orally to audiences anywhere. In this manner, throughout the long history of Sanskritization, literature became the most potent instrument in the dissemination of the Sanskritic culture. The Mahābhārata and the Rāmāyaṇa epics in particular played a crucial role in spreading this culture from the confined walls of the kraton to the countryside. As Srinivas (1989:61) observes in the context of Sanskritization in India, the epics "have not only transmitted to the people a knowledge of the great gods of Hinduism and certain basic theological ideas, but have also helped to spread common culture throughout the century. The epics, and the innumerable stories included in them, constitute the foundation of the literature in every Indian language. The fact that the institution of harikatha, or public reading of the epics and the Pūranas by trained masters of the art, was a popular pastime made it possible for Sanskritic Hinduism to reach even the illiterate masses."

The earliest evidence of the penetration of the Sanskrit epics into rural areas is found in the Sangsang copper plate inscription issued in the name of King Balitung in AD 907 to confirm the granting of freehold to the monastery of Dalinan (Sarkar 1971-72:II, 85-98). To celebrate what must have been the most important event of the year, if not of decades, for the whole region, a variety of performances was given on that occasion. Apart from singing (mamidu), dancing (mangigal), a Kicaka dance, play-acting (mamirus) and clowning (mabañol), the inscription also mentions a wayang performance (mawayang) of the story of "Bhimaya-kumara", and a recital (macarita) of the "Bhima-kumara" and "Rāmāyaṇa" stories. Both "Kicaka" and the "Bhīma-kumara" obviously refer to a certain episode from the Wirā țaparwa, the fourth book of the Mahābhārata (Zoetmulder 1974:208-209). Since there is no evidence that a Javanese translation or adaptation of the Mahābhārata already existed at that time, it seems likely that the narrator of the Bhīma-kumara episode recited a Sanskrit text, and then, as in a harikatha, explained it to his audience in Javanese. The mabasan in present-day Bali, in which people gather to listen to a recital of an Old Javanese poem and its interpretation in Balinese, no doubt originated from this kind of macarita. 


\section{The Javanization of the Mahābhārata}

It was some ninety years after the aforementioned macarita that the rendering of the Mahābhārata into Javanese was undertaken under the patronage of King Dharmawangśa Tĕguh(AD 990-1016) - about sixty years after the centre of power had moved from the central to the eastern part of the island. A most important event in relation to the rendering of the epic was a macarita at Dharmawangśa's court where people gathered to listen to a recital of the Wirāțaparwa for "one month minus one evening" - commencing on 14 October and ending on 12 November 996. The importance of the occasion is evident from the fact that the king himself attended all the sessions, except for one, "when the king was prevented by other affairs" (Juynboll 1912:97-98; Zoetmulder 1974:95). It is very likely, therefore, that this was the first recital - some kind of a première, as Zoetmulder suggests - of the first completed rendering of one of the eighteen books of the Mahābhārata. It is true that the Wirāțaparwa is not the first book of the Mahābhārata but, as Raghu Vira points out, "the Mahābhārata reciters commenced their sessions with the Virāța and not with Âdi [the first parvan]", because "the Virāța is one of the shortest of the major parvans, full of action and excitement" (Raghu Vira 1936:xvii). Of the eighteen books that constitute the Mahābhārata, only nine parwa, including the Wirātaparwa, have come down to us. Whether these nine were the only completed parwa, or other parwa had been written but later lost, is a question that is difficult to answer satisfactorily. In any case, in Old Javanese usage the term parwa includes not only the eighteen parwa of the Mahābhārata, but also the Old Javanese Uttarakaṇda, the final part of Valmiki's epic which is not found in the Old Javanese Rāmāyaṇa.

In the introductory section of the Wirāțaparwa we find an expression used by the anonymous writer to indicate the aim of his undertaking, namely mangjawākĕn Byāsamata - literally "to 'Javanize' Byāsa's thought". Another expression occurring in the epilogue is pinrakrta, a passive form of mrakrta, "to render (the story) into the vernacular". It is clear from comparing the Wirattaparwa and the other parwa with their Sanskrit originals that they are not translations, but rather adaptations of the latter. It is true that many passages in the parwa are in fact literal translations from the Sanskrit texts, but in general the Javanese writers merely present an abbreviated form of the metrical epic in Old Javanese prose which faithfully follows the epics in essence. Except for a few lines in the prologues and epilogues, the parwa writers did not insert any additions, nor make significant changes which would point to an independent attitude in their handling of the sources.

The writing of the parwa was not, however, the end of the "Javanization" of the Indian epics. It was soon followed by another process of "Javanization", which became apparent in the East Javanese kakawin and other literary products 
from the same period. Writing kakawin around themes taken from the parwa was undoubtedly a most popular exercise for East Javanese poets and, after the fall of Majapahit, for Balinese poets as well. The list of kakawin in Pigeaud's catalogue shows that more than half of them have heroes and heroines from the Indian epics as their main characters (Pigeaud 1967:157-197). There is, however, a big difference in the way the epic materials are handled in the kakawin and in the parwa. In the kakawin the "Javanization" was more than just substitution of a vernacular for Sanskrit as in the parwa and, to a lesser degree, the Old Javanese Rāmāyaṇa. It involved a more fundamental change: the transposition of what were basically still Indian narratives into a Javanese setting. All the names of the kingdoms and places where the stories take place, and those of the heroes and the heroines of the stories are, to be sure, Indian, and are known from the Indian epics. Thus we find, for instance, that in the twelfth century Bhāratayuddha kakawin the Pāndawas and the Korawas are fighting their final fraternal war for the kingdom of Hāstina in the field of battle at Kurukṣetra, and that in the fourteenth century Arjunawijaya kakawin, Arjuna Kartawīrya is fighting a fierce battle against Rāwaṇa on the banks of the Narmada river. Yet, as Zoetmulder remarks:

In spite of this, one cannot but be struck by the fact that these stories are placed in a setting that is definitely Javanese when reading the kakawins. Under the guise of Sanskrit personal and place names the poet is presenting a picture of his own country and his own society. These men and women with their Indian names are essentially Javanese, acting like Javanese, thinking like Javanese and living in a Javanese environment (1974:187-188).

It is thus possible for a poet to compose a poem woven around a theme taken from a parwa, but in fact telling the story of a Javanese king. For instance, the Arjunawiwaha (Arjuna's wedding), a kakawin written by mpu Kanwa around AD 1030, is generally accepted as being an allusion to the life story of King Erlangga, a ruler of the kingdom of Kahuripan, who was the poet's patron (Berg 1938). Likewise, other poets may have written kakawin, with certain princes, most likely their patrons, in mind (Robson 1983:302-309). Their contemporaries would no doubt have been able to identify the heroes and heroines of the kakawin with their princes and princesses, but without the benefit of knowing the life story of those princes and princesses it would have been impossible for later generations (and certainly for us) to know to whom the poets alluded. Not that that really mattered to them. In fact, it is very unlikely that readers of the Arjunawiwaha from, say, Kadiri of AD 1150, would have identified Arjuna with Erlangga, who by then had been dead for about a century. It seems most likely that those readers would have identified Arjuna with King Jayabhaya, the contemporary ruler of Kadiri. Likewise, readers of two centuries later 
would have identified him with King Rājasanāgara, the great ruler of fourteenth century Majapahit. In short, Arjuna and all the great heroes and villains of the Great Bhāratas and other Indian literary works continued to be related to contemporary Javanese life throughout the centuries. In this way Old Javanese literary works remained part of daily rituals for many centuries after the first "temple of language" was erected more than a thousand years ago — and in fact continue to be so in present-day Bali.

Creating "temples of languages" was a wiser decision of the Javanese rulers than building "temples of stone", and even more so than erecting "temples of gold". Long after the fabulous wealth accumulated by the Śriwwijayan rulers had vanished, both stone and language temples continued to function as refuges where devotees came to seek protection and blessings from the Lord. And long after all those hundreds of stone temples that covered the island of Java were in ruins - destroyed by earthquakes, volcanic eruptions or sheer neglect - and then fell into disuse and were abandoned when Islam came, quite a number of Old Javanese literary works continued to be in demand as a source of ethical and spiritual guidance in the Moslem Javanese kraton and for the Javanese population in general. Their Modern Javanese versions were, and are, even more popular than those derived from Islamic sources. It is certainly instructive to note that while Chandi Borobudur, undoubtedly the largest and the most majestic of all the "temples of stone", was buried under thick mud and tropical growth by the early nineteenth century (Soekmono 1976:5), Raffles was able to testify that at that time the Bhāratayuddha, one of the best known Old Javanese literary works, was "the most popular and celebrated poem in the [Javanese] language" (1965:410). It is still so in Bali today, where people still "meditate" inside all those "temples of language".

\section{References}

Ardika, I.W. and P.S. Bellwood

1991 Sembiran: the beginnings of Indian contact with Bali. Antiquity 65:221232.

Barret Jones, A.M.

1984 Early tenth century Java from the inscriptions: a study of economic, social and administrative conditions in the first quarter of the century. Verhandelingen van het Koninklijk Instituut voor Taal-, Land- en Volkenkunde 107. Dordrecht-Holland: Foris Publications.

Bellwood, P.S.

1985 Prehistory of the Indo-Malaysian archipelago. Sydney: Academic Press. 
Berg, C.C.

1938 De Arjunawiwaha, Er-langga's levensloop en bruiloftslied? Bijdragen tot de Taal-, Land-en Volkenkunde 97:19-94.

Bernet Kempers, A.J.

1980 The reliefs and the Buddhist texts. In Proceedings of the International Symposium on Chandi Borobudur, pp.92-105. Tokyo: Executive Committee for the International Symposium on Chandi Borobudur.

Blust, R.

1980 Early Austronesian social organization. Current Anthropology 21:203247.

Casparis, J.G. de

1950 Inscripties uit de cailendra-tijd. Bandung: A.C. Nix.

1956 Prasasti Indonesia II: selected inscriptions from the 7th to the 9th century A.D. Bandung: N.V. Masa Baru.

1975 Indonesian palaeography: a history of writing in Indonesia from the beginning to c.A.D. 1500. Leiden: E.J. Brill.

1990 Some notes on relations between central and local government in ancient Java. In D.G. Marr and A.C. Milner (eds) Southeast Asia in the 9th to 14th centuries, pp.49-63. Singapore: Institute of Southeast Asian Studies and Canberra: Research School of Pacific Studies, The Australian National University, Canberra.

Chhabra, B.Ch.

1965 Expansion of Indo-Aryan culture during Pallava rule (as evidenced by inscriptions). Delhi: Munshi Ram Manohar Lal.

Coedès, G.

1968 The Indianized states of Southeast Asia. Canberra: Australian National University Press.

Damais, L.C.

1949 Epigrafische aantekeningen: centraal gezag of koninkrijkjes? Tijdschrift voor Indische Taal-, Land-, en Volkenkunde 83:1-26.

Fox, J.J.

1990 The ordering of generations: change and continuity in Old Javanese kinship. In D.G. Marr and A.C. Milner (eds) Southeast Asia in the 9th to 14th centuries, pp.315-326. Singapore: Institute of Southeast Asian Studies and Canberra: Research School of Pacific Studies, The Australian National University. 
Gonda, J.

1973 Sanskrit in Indonesia. New Delhi: International Academy of Indian Culture. [2nd ed.]

Goody, J.

1968 Introduction. In J. Goody (ed.) Literacy intraditional societies, pp.1-26. Cambridge: Cambridge University Press.

Goris, R.

1954 Prasasti Bali, 2 vols. Bandung: N.V. Masa Baru.

Gough, K.

1968 Implications of literacy in traditional China and India. In J. Goody (ed.) Literacy in traditional societies, pp.70-84. Cambridge: Cambridge University Press.

Hall, D.G.E.

1981 A history of South-east Asia. 4th ed. London: Macmillan.

Hall, Kenneth R.

1985 Maritime trade and state development in early Southeast Asia. Honolulu: University of Hawaii Press.

Holt, Claire

1967 Art in Indonesia: continuities and change. Ithaca: Cornell University Press.

Hooykaas, C.

1958 The Old Javanese Rāmāyaṇa: an exemplarykakawin as to form and content. Verhandelingen der Koninklijke Nederlandse Akademie van Wetenschappen, Afdeeling Letterkunde, vol. 65, no. 1.

Juynboll, H.H.

1912 Wirātaparwa: Oudjavaans prozageschrift. 's-Gravenhage: Koninklijk Instituut voor Taal-, Land- en Volkenkunde, Martinus Nijhoff.

Keith, A.B.

1956 A history of Sanskrit literature. London: Oxford University Press.

Krom, N.J.

1927 Barabudur: archaelogical description. 2vols. The Hague: Koninklijk Instituut voor Taal-, Land- en Volkenkunde, Martinus Nijhoff. 
Kulke, $\mathrm{H}$.

1990 The early and the imperial kingdom in Southeast Asian history. In D.G. Marr and A.C. Milner (eds) Southeast Asia in the 9th to 14th centuries, pp.1-22. Singapore: Institute of Southeast Asian Studies and Canberra: Research School of Pacific Studies, The Australian National University.

Leur, J.C. van

1967 Indonesian trade and society: essays in Asian social and economic history. The Hague: W. van Hoeve Publishers.

Mabbett, I.W.

1977 The 'Indianization' of Southeast Asia: reflection on thehistorical sources. Journal of Southeast Asian Studies 8:143-160.

Naerssen, F.H. van

1977 The economic and administrative history of early Indonesia. In F.H. van Naerssen and R.C. de Iongh (eds) The economic and administrative history of early Indonesia. Leiden: E.J. Brill.

Pigeaud, Th.G.Th.

1960-63 Java in the fourteenth century: a study in cultural history, 5 vols. The Hague: Koninklijk Instituut voor Taal-, Land- en Volkenkunde, Martinus Nijhoff.

1967 Literature of Java: catalogue raisonne of Javanese manuscripts in the Library of the University of Leiden and other public collections in the Netherlands, vol. I. The Hague: Koninklijk Instituut voor Taal-, Landen Volkenkunde, Martinus Nijhoff.

Raffles, T.S.

1965 The history of Java. Kuala Lumpur: Oxford University Press [reprint of 1817].

Raghu Vira

1936 The Virātaparvan, being the fourth book of the Mahābhārata. Poona: Bhandarkar Oriental Research Institute.

Robson, S.O.

1980 The Rāmāyaṇa in early Java. South East Asian Review 5:5-19.

1983 Kakawin reconsidered: toward a theory of Old Javanese poetics. Bijdragen tot de Taal-, Land-en Volkenkunde 139:291-319. 
Sarkar, H.B.

1971-72 Corpus of the inscriptions of Java, 2 vols. Calcutta: Firma K.L. Mukhopadhyay.

Soekmono, R.

1976 Chandi Borobudur: a monument of mankind. Assen/Amsterdam: van Gorcum.

1979 The archaeology of Central Java before 800 A.D. In R.B. Smith and W. Watson (eds) Early South East Asia: essays in archaelogy, history and historical geography, pp.457-472. New York: Oxford University Press.

Srinivas, M.N.

1956 A note on Sanskritization and westernization. The Far Eastern Quarterly 15:481-496.

1966 Social change in modern India. Berkeley: University of California Press.

1989 The cohesive role of Sanskritization and other essays. Delhi: Oxford University Press.

Stutterheim, W.

1933 Iets over raka en rakryan naar aanleiding van Sindok's dynastieke positie. Tijdschrift voor Indische Taal-, Land- en Volkenkunde 73:159171.

1989 Rāma-legends and Rāma-reliefs in Indonesia. New Delhi: Indira Gandhi National Centre for the Arts/ Abhinav Publications [translation of 1925].

Supomo, S.

1977 Arjunawijaya: a kakawin of mpu Tantular. The Hague: Koninklijk Instituut voor Taal-, Land- en Volkenkunde, Martinus Nijhoff.

1979 The image of Majapahit in later Javanese and Indonesian writing. In A. Reid and D.G. Marr (eds) Perceptions of the past in Southeast Asia, pp.171-185. Singapore: Heinemann Educational Books (Asia).

Takakusu, J.

1966 A record of the Buddhist religion as practised in India and the Malay Arhipelago (A.D. 671-695) by I-tsing. Delhi: Munshiram Manoharlal. [reprint of 1896].

Vogel, J.Ph.

1918 The yūpa inscriptions of King Mūlavarman from Koetei (East Borneo). Bijdragen tot de Taal-, Land- en Volkenkunde 74:216-218. 
Wheatley, P.

1961 The golden Khersonese: studies in the historical geography of the Malay Peninsula before A.D. 1500. Kuala Lumpur: University of Malaya Press.

Winstedt. R.O.

1977 A history of classical Malay literature. Kuala Lumpur: Oxford University Press (Oxford in Asia Historical Reprints edition).

Wisseman Christie, J.

1983 Raja and rama: the classical state in early Java. In L. Gessick (ed.) Centres, symbols and hierarchies: essays on the classical states of Southeast Asia, pp.9-44. Yale University Southeast Asia Studies: Monograph Series 26.

1990 Negara, mandala, and despotic state: images of early Java. In D.G. Marr and A.C. Milner (eds) Southeast Asia in the 9th to 14th centuries, pp.65-93. Singapore: Institute of Southeast Asian Studies and Canberra: Research School of Pacific Studies, Australian National University, Canberra.

Wolters, O.W.

1970 The fall of śrivijaya in Malay history. London: Lund Humphries.

1982 History, culture, and region in Southeast Asian perspectives. Singapore: Institute of Southeast Asian Studies.

Zoetmulder, P.J.

1974 Kalangwan: a survey of Old Javanese literature. The Hague: Koninklijk Instituut voor Taal-, Land- en Volkenkunde,

Martinus Nijhoff.

1982 Old Javanese-English dictionary. 's-Gravenhage: Koninklijk Instituut voor Taal-, Land- en Volkenkunde, Martinus Nijhoff.

\section{Notes}

\footnotetext{
${ }^{1}$ A somewhat similar case is Malyāng, a small principality in north-western Cambodia during the seventh century which, according to Wolters (1982:3), disappeared from the records after the late eighth century but reappeared in the late twelfth century as a rebellious area when Angkor was sacked by the Cham in 1177.

2 This is according to Sarkar's interpretation (1971-72:I, 15-24, note 43). For a different interpretation, which says that Sañjaya was the son of Sannāha's sister, see Chhabra (1965:48) and Coedès (1968:87).

${ }^{3}$ Other scholars, such as Kern, Rouffaer and Krom, argue that since Sanskrit yava could also apply to cereal products in general, Yava may have derived from jawawut, a Javanese word for "millet", which is an ancient cultigen in Java (see Gonda 1973:349).

${ }^{4}$ For recent studies on rakai and watak, and local government in ancient Java in general, see for example Barret Jones (1984), de Casparis (1990) and Wisseman Christie (1983, 1990).

${ }^{5}$ See Barret Jones (1984:93), Zoetmulder (1982), under rake, kaki, ki, kya and kyayi. The element ke or ki is probably related to Proto-Austronesian *aki, which may refer to "grandfather" (Blust 1980:219).
} 
${ }^{6}$ A brief survey of Javanese terms of kinship also clearly shows that "the old Javanese kinship system is entirely Austronesian and, in its basic conceptions, shows little if any Sanskrit influence" (Fox 1990:325).

${ }^{7}$ For the process of state formation through three successive phases, i.e. local, regional and imperial, see Kulke (1990).

${ }^{8}$ For a detailed description of the so-called Later Pallava script and the adaptation required for the writing of Old Malay inscriptions, see de Casparis (1975:20-27).

${ }^{9}$ My colleague Dr Virginia Hooker has kindly drawn my attention to various pre-Moslem motifs occurring in Malay literature, such as "the foam princess" and "the bamboo princess", but I believe that they are motifs from the pre-Hindu period and more likely to have been transmitted to later Malay literature through the oral tradition.

${ }^{10}$ The term ca i bhāṣa occurs, for instance, in the Arjunawijaya (1.2): “The purpose of my praise to the Lord is to implore Him to pay heed to the reverential homage of one who devotes himself to poetry, so that he may achieve the perfect goal he set himself in writing — this is what I implore, as I build my temple of language on my writing board" (Supomo 1977). For the conception of kakawin as "language temple", see Zoetmulder (1974:173-185).

${ }^{11}$ The dating is uncertain. The first quarter of the tenth century is generally accepted as the most likely date of its composition (see Zoetmulder 1974:230-231), but more recently Robson $(1980,1983)$ argues that it should be assigned to the middle of the ninth century.

${ }^{12}$ In a harikatha the priest reads and explains a religious story to his audience. Each story takes a few weeks to complete, the audience meeting for a few hours every evening in a temple. The faithful believe that such listening leads to the acquisition of spiritual merit (Srinivas 1956:485). 